\title{
Systematic Review of Intervention Practices for Depression in the Workplace
}

\author{
Andrea D. Furlan • William H. Gnam • Nancy Carnide • Emma Irvin • \\ Benjamin C. Amick III - Kelly DeRango - Robert McMaster • Kimberley Cullen • \\ Tesha Slack • Sandra Brouwer • Ute Bültmann
}

Published online: 10 December 2011

(C) The Author(s) 2011. This article is published with open access at Springerlink.com

\begin{abstract}
Design Systematic Review. Objective To determine which intervention approaches to manage depression in the workplace have been successful and yielded value for employers in developed economies. Data Sources We searched MEDLINE, EMBASE, CINAHL, Central, PsycINFO, and Business Source Premier up to June 2010 using search terms in four broad areas: work setting, depression, intervention, and work outcomes. Study Selection Two independent reviewers selected potential articles that met the following criteria: working age individuals with mild or moderate depression; interventions or
\end{abstract}

Access to Data Andrea Furlan had full access to all of the data in the study and takes responsibility for the integrity of the data and the accuracy of the data analysis.

Electronic supplementary material The online version of this article (doi:10.1007/s10926-011-9340-2) contains supplementary material, which is available to authorized users.

A. D. Furlan $(\bowtie) \cdot$ W. H. Gnam · N. Carnide - E. Irvin ·

B. C. Amick III - K. Cullen · T. Slack

Institute for Work \& Health, 481 University Av. Suite 800,

Toronto, ON M5G 2E9, Canada

e-mail: afurlan@iwh.on.ca

A. D. Furlan · R. McMaster

Department of Medicine, University of Toronto, Toronto,

Canada

A. D. Furlan

Toronto Rehabilitation Institute, Toronto, Canada

W. H. Gnam

Centre for Addiction \& Mental Health, Toronto, Canada

N. Carnide

Dalla Lana School of Public Health, University of Toronto,

Toronto, Canada programs that were workplace-based or could be implemented and/or facilitated by the employer; inclusion of a comparator group in the analysis; outcomes of prevention, management, and recurrences of work disability or sickness absence, and work functioning. Methods Two reviewers independently reviewed each article for quality and extracted data using standardised forms. Following guidelines from the GRADE Working Group, the quality of evidence addressing each outcome was graded as high, moderate, low, or very low on the basis of six criteria: study design, risk of bias, consistency, generalisability, data precision, and economic benefit. Using this information and following Cochrane Collaboration guidelines, the findings for each intervention were summarised and key messages were developed. Results We identified ten randomised trials and two non-randomised studies from various countries and jurisdictions that evaluated a wide range of intervention practices. The evidence was graded as

B. C. Amick III

Division of Health Promotion \& Behavioral Sciences, School of Public Health, University of Texas, Houston, TX, USA

B. C. Amick III

Southwest Center for Occupational \& Environmental Health, Houston, TX, USA

K. DeRango

DeRango \& Associates, LLC, Kalamazoo, MI, USA

K. Cullen

Biophysics Interdisciplinary Group, University of Guelph,

Guelph, Canada

\section{S. Brouwer · U. Bültmann}

Department of Health Sciences, Community \& Occupational

Medicine, University Medical Center Groningen, University of Groningen, Groningen, The Netherlands 
"very low" for all outcomes identified. Therefore, no intervention could be recommended. Conclusions To date, there is insufficient quality of evidence to determine which interventions are effective and yield value to manage depression in the workplace.

Keywords Depression - Workplace - Systematic review

\section{Introduction}

Depression is a widespread, disabling psychiatric illness with far-reaching personal and economic consequences [1, 2]. By the year 2020, depression will be the second largest burdensome illness in developed economies [3]. In addition to its adverse individual effects, the associated workplace effects of depression are extensive. Employees with depression report significantly more health-related lost productive time than those without depression [4-6], higher rates of absenteeism and short-term disability spells [7], and higher rates of job turnover [8]. Economic analyses have consistently demonstrated that the costs of lost productivity associated with depression far exceed the costs of resources utilised to treat and manage the disorder [9]. Furthermore, depression has been shown to be one of the most costly of common health conditions that affect the ability to work and work (or job) performance [5, 10-13].

Not surprisingly, many employers offer Employee Assistance Programs, health promotion or wellness programs, yet employer-sponsored programs that specifically target depression in the workplace remain uncommon [14]. There are information gaps that may prevent employers from making further investments to reduce the impact of depression in the workplace. The most significant gap may be the paucity of readily accessible information on targeted interventions that improve work-related outcomes, such as reducing absenteeism and productivity loss at work [13]. Consequently, we undertook a systematic review to identify evidence-based programs, or intervention approaches that could be implemented or facilitated by employers to manage workers' depression and reduce associated productivity losses.

\section{Methods}

The systematic review methods were adapted from a process developed by the Cochrane Collaboration [15]. The review team included 11 researchers from Canada, United States, and Europe from various disciplines. The research question addressed was: "Which intervention approaches to manage depression in the workplace have been successful and yielded value for employers in developed economies?"
Stakeholder Engagement

Two meetings with stakeholders (representing the Ontario Ministry of Health and Long-Term Care, the Ontario Ministry of Government Services, insurance providers, disability management service providers, mental health organisations, mental health disorder survivors, organised labour, and employers) were conducted to solicit input related to the research question, literature search terms, presentation of the findings, messages, and appropriate communication channels.

Criteria for Inclusion of Studies

(P) Population: Men and/or women of working age (i.e. 18-65 years old) with depression. Depression was defined as "current or remitted depression" identified using one of the following methods: a screening interview or instrument, a clinician-derived diagnosis, a diagnosis established using formal standardised diagnostic criteria, or validated self-report instruments. Studies that included participants with other mental health disorders were included only if $50 \%$ or more had depression. Studies were excluded if the focus was on severe mental disorders (i.e., bipolar disorder or schizophrenia, or chronic severe depression that precluded patients from any meaningful labour market participation) and where the primary focus was on persons with alcohol or other substance abuse or dependence disorders, depression related to pregnancy, and depression in military and veterans populations. Studies primarily focused on bereavement, burnout, and anxiety were also excluded.

(I) Intervention: Studies evaluating programs or interventions that were workplace-based or that could be explicitly implemented and/or facilitated by the employer were included. Workplace or work setting was defined as any location where a worker performs his or her assigned work. Studies of in-patient intervention programs and those focusing entirely on drug treatment of depression were excluded.

(C) Comparison/Control: Any study with a comparator group was included. This included randomised controlled trials as well as non-randomised studies.

(O) Outcomes: Work-relevant outcomes included: sickness absence (leave), absenteeism, worker turnover, longterm disability, on-the-job health-related performance, work-functioning (productivity) and injury rates.

The review team considered published or in-press peerreviewed scientific articles. There were no language restrictions. Book chapters, dissertations, and conference proceedings were excluded. 
Search Methods for Identification of Studies

Key terms were identified and combined to search the following databases from their inception dates: MEDLINE, EMBASE, CINAHL, Central, PsycINFO and Business Source Premier up to June 2010. Both database-specific controlled vocabulary terms and keywords were included. The complete list of terms used and the detailed search strategy are presented in Appendix 1-Electronic supplementary material. The reference lists in review articles and articles included were also checked.

Selection of Studies, Risk of Bias Assessment, and Data Extraction

Study selection, risk of bias assessment, and data extraction were conducted independently by two members of the review team in rotating pairs that were randomly selected from the pool of 11 authors. All authors participated in all tasks. Titles, abstracts, and full articles were evaluated to exclude articles that did not meet the inclusion criteria (Appendix 2-Electronic supplementary material). Reviewers entered responses for all levels of review on commercial review software, DistillerSR [16], allowing centralised article tracking and access.

Risk of bias was conducted using a protocol adapted from the Cochrane Collaboration. Responses from 18 quality criteria questions (Appendix 3-Electronic supplementary material) were grouped to form a set of criteria used to judge risk of five biases: (1) selection bias; (2) attrition bias; (3) performance bias; (4) measurement bias; and (5) reporting bias [15]. For each type of bias, the risk was determined to be low, moderate, or high. An article was considered to be overall at high risk for bias if the risk of any one bias type was rated high.

Data were extracted using a standardised data extraction form based on existing forms and data extraction procedures $[17,18]$. A classification framework was established to categorise the work-related outcomes reported in the studies of this review into one of four categories, as suggested by stakeholders (see Table 1). Quantitative pooling of results was not possible due to outcome measure heterogeneity, study methods, and lack of data necessary to calculate effect sizes.

\section{Evidence Synthesis}

The quality of evidence and strength of recommendations were adapted from the Grading of Recommendations Assessment, Development and Evaluation Working Group [19]. (Appendix 4-Electronic supplementary material) The summary of findings and key messages were developed following published guidelines from the Cochrane
Collaboration [15]. For each intervention assessed, the findings corresponding to each work-relevant outcome category were classified as positive, negative, or neutral, depending respectively upon whether the intervention group was statistically significantly better $(P<0.05)$, worse $(P<0.05)$ or not different $(P \geq 0.05)$ from the control group. Key messages for each intervention approach were extracted following the framework shown in Table 2 for those studies employing an inactive control group (e.g., usual care).

\section{Results}

\section{Description of Studies}

The search of electronic databases yielded 4,214 articles. After reviewing the titles and abstracts, we identified 293 articles for full-article relevance screening. Following their review, 21 articles proceeded to quality appraisal. Seven additional articles were excluded at the risk of bias assessment and data extraction stages because they did not meet inclusion criteria, resulting in 14 included articles from 12 studies. Figure 1 summarises the study selection process.

\section{Study Characteristics (See Appendix 5-Electronic Supplementary Material)}

Of the studies identified, four were conducted in The Netherlands [20-24], four in the USA [25-29] and one each in Canada, Finland, Denmark, and Japan [30-34]. Ten were randomised controlled trials (RCTs) [20-29, 31-33] and two were non-randomised studies (NRSs) with a separate control group [30, 34]. Studies were conducted in a variety of settings, including workplaces [20, 29, 30,34], primary care practices [25-28], occupational health services [21, 22, 24], and specialty medical clinics [23, 31-33].

In some studies, all participants were working at baseline [28, 29, 34], while in others, all participants were on work disability leave [30] or sick leave [20-22, 24]. Four studies included a mix of participants who were working, on sick leave, or unemployed [23, 25, 31-33]. One study did not report working status at baseline [27].

Interventions

Table 3 summarises the interventions. The 12 studies identified cover a diverse range of interventions that include psychological interventions [20, 31, 32], enhanced primary care [25-28], enhanced psychiatric care [23], enhanced occupational physician roles [21, 22, 24], 
Table 1 Framework of work-related outcomes relevant to review stakeholders

\begin{tabular}{|c|c|c|c|c|}
\hline $\begin{array}{l}\text { Outcome } \\
\text { category }\end{array}$ & $\begin{array}{l}\text { Prevention of work disability/ } \\
\text { sickness absence }\end{array}$ & $\begin{array}{l}\text { Management of work } \\
\text { disability/sickness absence }\end{array}$ & $\begin{array}{l}\text { Work functioning (on- } \\
\text { the-job health-related } \\
\text { performance) }\end{array}$ & $\begin{array}{l}\text { Recurrence of work } \\
\text { disability/sickness absence }\end{array}$ \\
\hline $\begin{array}{l}\text { Relevant study } \\
\text { population }\end{array}$ & $\begin{array}{l}\text { Depressed workers, currently } \\
\text { working and not on work } \\
\text { disability leave/sickness } \\
\text { absence }\end{array}$ & $\begin{array}{l}\text { Depressed workers currently } \\
\text { on work disability leave/ } \\
\text { sickness absence due to their } \\
\text { depression }\end{array}$ & $\begin{array}{l}\text { Depressed workers, } \\
\text { currently working and } \\
\text { not on work disability } \\
\text { leave/sickness absence }\end{array}$ & $\begin{array}{l}\text { Depressed workers who are } \\
\text { currently working, but have } \\
\text { had a prior episode of work } \\
\text { disability/sickness absence } \\
\text { due to their depression }\end{array}$ \\
\hline $\begin{array}{l}\text { Among this } \\
\text { study } \\
\text { population, is } \\
\text { there an } \\
\text { effective } \\
\text { intervention } \\
\text { to: }\end{array}$ & $\begin{array}{l}\text { Promote stay at work, promote } \\
\text { job retention, or prevent or } \\
\text { reduce the number of casual } \\
\text { sick leave days taken due to } \\
\text { depression (e.g., use of } \\
\text { vacation days or unpaid sick } \\
\text { days) or paid sickness absence } \\
\text { days? }\end{array}$ & $\begin{array}{l}\text { Promote a return to work, } \\
\text { hasten a return to work, } \\
\text { prevent the transition from } \\
\text { short-term work disability } \\
\text { leave to long-term leave, or } \\
\text { prevent the transition from } \\
\text { sickness absence to work } \\
\text { disability? }\end{array}$ & $\begin{array}{l}\text { Maintain or improve a } \\
\text { worker's functioning } \\
\text { both in terms of } \\
\text { productivity and } \\
\text { performance? }\end{array}$ & $\begin{array}{l}\text { Prevent or reduce recurrences } \\
\text { of work disability leave/ } \\
\text { sickness absence due to } \\
\text { depression? }\end{array}$ \\
\hline $\begin{array}{l}\text { Outcome } \\
\text { measures }\end{array}$ & $\begin{array}{l}\text { Number of causal sick leave days } \\
\text { or vacation days } \\
\text { Number of paid sickness absence } \\
\text { or sick leave days } \\
\text { Hours worked } \\
\text { Job retention } \\
\text { Transition to work disability } \\
\text { leave }\end{array}$ & $\begin{array}{l}\text { Return to work } \\
\text { Duration on work disability } \\
\text { leave/sickness absence } \\
\text { Transition from short-term } \\
\text { disability to long-term } \\
\text { disability } \\
\text { Transition from sickness } \\
\text { absence to work disability }\end{array}$ & $\begin{array}{l}\text { Productivity and } \\
\text { performance measures } \\
\text { (e.g., Work Ability } \\
\text { Index, Health and } \\
\text { Work Performance } \\
\text { questionnaire) }\end{array}$ & $\begin{array}{l}\text { Recurrence of work } \\
\text { disability/sickness absence } \\
\text { Number of work disability/ } \\
\text { sickness absence } \\
\text { recurrences } \\
\text { Duration of a recurrent work } \\
\text { disability leave/sickness } \\
\text { absence }\end{array}$ \\
\hline
\end{tabular}

Table 2 Translation from summary of findings to key messages

\begin{tabular}{|c|c|c|}
\hline GRADE & Consistency & Terminology for key messages \\
\hline \multirow[t]{2}{*}{ High } & Intervention is consistently better* than inactive control & Recommendation to implement the intervention \\
\hline & Intervention is consistently inferior to inactive control $* *$ & $\begin{array}{l}\text { Recommendation against implementation of the } \\
\text { intervention }\end{array}$ \\
\hline \multirow{2}{*}{$\begin{array}{l}\text { Moderate or } \\
\text { low }\end{array}$} & Intervention is consistently better than inactive control & Practice consideration or promising practice ${ }^{a}$ \\
\hline & Intervention is consistently inferior to inactive control & No recommendation. Need for more research \\
\hline Very low & $\begin{array}{l}\text { Intervention is consistently better than or inferior to inactive } \\
\text { control }\end{array}$ & No recommendation. Need for more research \\
\hline Any & Findings are mixed $* * *$ or contradictory $* * * *$ & No recommendation. Need for more research \\
\hline
\end{tabular}

* Consistently better: When all the comparisons for primary outcomes demonstrated positive findings (i.e., in favour of the intervention group) ** Consistently inferior: When all the comparisons for primary outcomes demonstrated negative findings (i.e., in favour of the control group) *** Mixed findings: When the comparisons for primary outcomes were a mix of positive and neutral (no difference between intervention and control) findings or a mix of negative and neutral findings

**** Contradictory findings: When the comparisons for primary outcomes were a mix of positive and negative findings

${ }^{a}$ Practice considerations or promising practice: refers to interventions that a group may try in collaboration with an evaluator to further assess the utility of the approach. These practices still require high quality evidence, but the evidence to date suggests there is promise in the effectiveness of the intervention

integrated care management [29, 30], exercise [33], and a worksite intervention [34].

The psychological interventions involved psychological treatments, such as cognitive behavioural therapy (CBT) and psychotherapy, which are normally delivered by psychologists or psychotherapists. However, in one trial [20], one of the interventions (brief CBT-based stress management with a focus on improving workplace processes) was delivered by "labour experts". Enhanced primary care involved physicians and nurses working in the primary care centres or managed care organizations. The predominant components of this approach were education for physicians and nurses on guideline-concordant care and reinforcement to adhere to these guidelines. Enhanced psychiatric care involved out-patient psychiatric treatment enhanced by occupational therapy. Enhanced occupational physician 
Fig. 1 Flowchart of studies

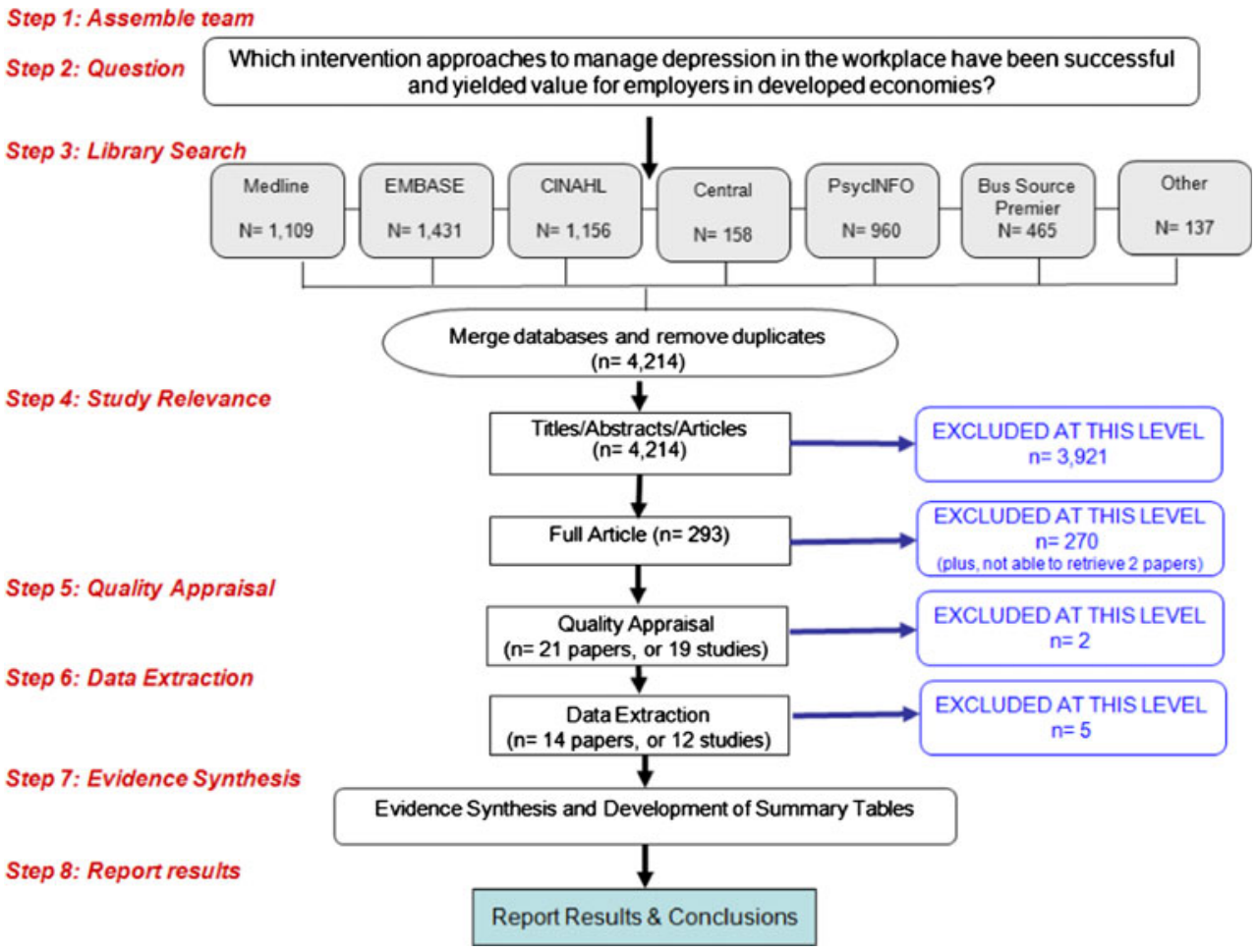

role consisted of an intervention approach that was aimed at establishing a more active role for the occupational physician in the management of work disability and in the prevention of work disability recurrences. Systems integration and care management interventions refer to interventions conducted at the organizational or health-care system level. In this systematic review, the interventions were aimed at appropriate diagnosis, adherence to treatment, adequate follow-up, and ensuring collaboration among all individuals involved in the care management of workers with depression. The exercise intervention consisted of three different types of exercises (strength, aerobic and relaxation training) without an "inactive" control group. People with depression were referred from general practitioners, private practicing psychiatrists, psychologists or psychiatric wards to participate in exercise training twice a week for 32 weeks in a hospital setting. The worksite intervention consisted of a stress reduction program in which supervisors were asked to list possible work stressors in their worksites and to make plans to reduce these stressors while a working committee made the plans feasible. The supervisors started stress reduction activities and the committee monitored their activity periodically.

Risk of Bias in Included Studies

Overall, each study demonstrated a high risk of at least one type of bias (Table 4). All 12 studies were judged to be at an overall high risk of bias, which reduces the certainty of the findings.

A high risk of selection bias was most common and was due to inadequate allocation methods [29, 30, 34], lack of information on allocation methods [20, 25-28], differences between participants and non-participants [25, 26, 28] and baseline differences [23, 33, 34].

Four studies demonstrated a high risk of attrition bias [27, 29, 31, 32, 34] due to important differences between those who remained in the study and those who were lost to follow-up.

Risk of performance bias was high in a number of studies due to failure to report on participants' compliance with their assigned intervention [21, 22, 24, 29, 31, 32, 34], as well as issues of contamination [21-24, 33] and cointervention [33].

Only two studies [31-33] demonstrated a high risk of measurement bias owing to the lack of blinded outcome assessment.

Reporting bias was high in three studies [25-27, 29] due to the use of multiple imputations for large quantities of missing data.

\section{Evidence Synthesis}

As all of the studies were judged to have high risk of bias and many outcomes-based on evidence from only one 
Table 3 Intervention characteristics

\begin{tabular}{|c|c|c|c|c|}
\hline Category of intervention & Intervention description & Intervention provider & $\begin{array}{l}\text { Employment and baseline } \\
\text { work status }\end{array}$ & Studies \\
\hline \multirow[t]{2}{*}{$\begin{array}{l}\text { Psychological } \\
\text { interventions }\end{array}$} & Cognitive-behavioural therapy & Psychologists (CBT) & $\begin{array}{l}\text { Self-employed, } 100 \% \text { on } \\
\text { sick leave }\end{array}$ & Blonk [20] \\
\hline & $\begin{array}{l}\text { Brief solution-focused psychotherapy } \\
\text { Short-term psychodynamic } \\
\text { psychotherapy } \\
\text { Long-term psychodynamic } \\
\text { psychotherapy }\end{array}$ & $\begin{array}{l}\text { Therapists with } \\
\text { qualifications in the } \\
\text { specific psychotherapy } \\
\text { delivered }\end{array}$ & $\begin{array}{l}80.7 \% \text { Employed, working } \\
\text { or studying at baseline } \\
19.3 \% \text { unemployed }\end{array}$ & Knekt $[31,32]$ \\
\hline \multirow[t]{2}{*}{$\begin{array}{l}\text { Enhanced primary care } \\
\text { delivered by } \\
\text { physicians and nurses }\end{array}$} & $\begin{array}{l}\text { Enhanced care delivered by primary } \\
\text { care physicians and nurses }\end{array}$ & $\begin{array}{l}\text { Physicians and nurse care } \\
\text { managers }\end{array}$ & $\begin{array}{l}45.3 \% \text { unemployed } \\
54.7 \% \text { employed, full or } \\
\text { part-time }\end{array}$ & $\begin{array}{l}\text { Lo Sasso [25]; } \\
\text { Rost [26]; } \\
\text { Smith [28] }\end{array}$ \\
\hline & $\begin{array}{l}\text { Quality improvement program for } \\
\text { improved psychotherapy with } \\
\text { primary care clinicians } \\
\text { Quality improvement program for } \\
\text { improved access to medications with } \\
\text { primary care clinicians }\end{array}$ & $\begin{array}{l}\text { "Practice therapists" for } \\
\text { psychotherapy } \\
\text { Nurses for medication } \\
\text { follow-up }\end{array}$ & $\begin{array}{l}63.1 \% \text { employed } \\
36.9 \% \text { unemployed }\end{array}$ & $\begin{array}{l}\text { Schoenbaum } \\
\text { [27] }\end{array}$ \\
\hline $\begin{array}{l}\text { Psychiatry plus } \\
\text { occupational therapy }\end{array}$ & $\begin{array}{l}\text { Psychiatric treatment with adjuvant } \\
\text { occupational therapy }\end{array}$ & $\begin{array}{l}\text { Psychiatrists and } \\
\text { occupational therapists }\end{array}$ & $\begin{array}{l}\text { Employed, but reduced or } \\
\text { no work hours for } \\
10 \text { weeks to } 2 \text { years. } \\
19.4 \% \text { had reduced part- } \\
\text { time hours, } 80.6 \% \text { were } \\
\text { absent }\end{array}$ & Schene [23] \\
\hline \multirow[t]{2}{*}{$\begin{array}{l}\text { Enhanced occupational } \\
\text { physician role }\end{array}$} & $\begin{array}{l}\text { Guideline-based care by occupational } \\
\text { physician }\end{array}$ & Occupational physicians & Employed, on sick leave & $\begin{array}{l}\text { Rebergen }[21 \text {, } \\
\text { 22] }\end{array}$ \\
\hline & $\begin{array}{l}\text { Occupational physicians with } \\
\text { specialised training }\end{array}$ & Occupational physicians & $\begin{array}{l}\text { Employed, with an } \\
\text { absence spell of at least } \\
6 \text { weeks }\end{array}$ & $\begin{array}{l}\text { van der Feltz- } \\
\text { Cornelis [24] }\end{array}$ \\
\hline \multirow[t]{2}{*}{$\begin{array}{c}\text { Integrated care } \\
\text { management }\end{array}$} & $\begin{array}{l}\text { Collaborative mental health program } \\
\text { (enhanced disability management) }\end{array}$ & Psychiatrists & $\begin{array}{l}\text { Employed, } 100 \% \text { on short- } \\
\text { term work disability }\end{array}$ & Dewa [30] \\
\hline & $\begin{array}{l}\text { Telephone screening, outreach, and } \\
\text { care management }\end{array}$ & $\begin{array}{l}\text { Masters-level mental health } \\
\text { clinicians }\end{array}$ & Employed, 100\% working & Wang [29] \\
\hline Exercise & $\begin{array}{l}\text { Strength training; aerobic training; } \\
\text { relaxation training }\end{array}$ & Physiotherapists & $\begin{array}{l}44.2 \% \text { unemployed } \\
46.1 \% \text { sick leave } \\
9.7 \% \text { working }\end{array}$ & Krogh [33] \\
\hline Worksite intervention & Worksite stress reduction program & Worksite supervisors & Employed, 100\% working & $\begin{array}{l}\text { Kawakami } \\
{[34]}\end{array}$ \\
\hline
\end{tabular}

study-lacked precision and consistency, the grade of evidence in all cases was considered to be "very low".

Half of the studies assessed the impact of an enhanced physician role. However, the type of enhancements and quality improvements were very different and varied according to the distinct disability insurance and health care system in place. Primary care enhancements were conducted in the USA [25-28] and included education on guideline-concordant interventions, screening for depression, and more frequent contacts with patients especially regarding adherence to treatments (pharmacological or psychotherapy). The results from these studies were mixed (positive and neutral). In another study [23], psychiatric care was enhanced by the addition of an occupational therapist that focused on contacting the worker and the employer to discuss a program for work reintegration. This study was conducted in The Netherlands and the results were mixed (positive and neutral). An enhanced occupational physician role was examined in two studies from The Netherlands [21, 22, 24] where they evaluated a more active role for the physician by guideline-based education and facilitation of RTW. The results were mixed (positive and neutral).

The studies examining integrated care management showed mixed findings (positive and neutral) [29, 30] and one study of a psychological intervention that used an inactive control [20] showed mixed findings (positive and neutral, and negative and neutral). One study of a worksite 
Table 4 Overall risk of bias across studies

\begin{tabular}{|c|c|c|c|c|c|c|}
\hline \multirow[t]{2}{*}{ Author* } & \multicolumn{6}{|l|}{ Bias } \\
\hline & $\begin{array}{l}\text { Selection } \\
\text { bias }\end{array}$ & $\begin{array}{l}\text { Attrition } \\
\text { bias }\end{array}$ & $\begin{array}{l}\text { Performance } \\
\text { bias }\end{array}$ & $\begin{array}{l}\text { Measurement } \\
\text { bias }\end{array}$ & $\begin{array}{l}\text { Reporting } \\
\text { bias }\end{array}$ & $\begin{array}{l}\text { Overall risk } \\
\text { judgement }\end{array}$ \\
\hline Blonk [20] & & $\theta$ & & $\theta$ & $\theta$ & High \\
\hline Dewa [30] & & $\theta$ & & $\theta$ & $\ominus$ & High \\
\hline Smith [28] & & & $\theta$ & $\theta$ & $\theta$ & High \\
\hline Rebergen $[21,22]$ & & & & $\theta$ & E & High \\
\hline van der Feltz-Cornelis [24] & & & & & 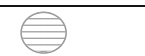 & High \\
\hline Schene [23] & & & & 皇 & $\theta$ & High \\
\hline Krogh [33] & & 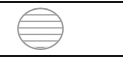 & & & 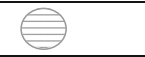 & High \\
\hline Kawakami [34] & & & & & & High \\
\hline Knekt $[31,32]$ & & & & & & High \\
\hline Lo Sasso [25]; Rost [26] & & & $\theta$ & & & High \\
\hline Wang [29] & & & & $\theta$ & & High \\
\hline Schoenbaum [27] & & & & & & High \\
\hline
\end{tabular}

Legend: $\oslash$ = criteria met; $\bigcirc=$ unclear if criteria met due to insufficient information; $\bigcirc=$ criteria not met

* Ordered according to ascending number of high risk bias categories in each study

stress reduction program was conducted in Japan and showed positive findings [34]. One trial of exercise did not have an inactive control group [33].

Because the evidence was graded as "very low" for all outcomes identified, the key message from this review is that some intervention approaches are feasible and could therefore be further evaluated in future studies:

- Enhanced Primary Care

- Enhanced Psychiatric Care

- Enhanced Role for the Occupational Physician

- Psychological Interventions

- Worksite Stress Reduction

- Integrated Care Management

\section{Discussion}

Our systematic review was designed to answer the question: "Which intervention approaches to manage depression in the workplace have been successful and yielded value for employers in developed economies?" We included ten randomised trials and two non-randomised studies from various countries and jurisdictions that evaluated a wide range of intervention practices to manage the impact of mild to moderate depression in the workplace. The evidence derived from all studies and intervention approaches for the primary outcomes of interest was graded as "very low" in all cases. A combination of factors contributed to this grade of evidence: the high risk of bias in all included studies, the paucity of studies for each outcome, which affected the consistency and precision of the evidence, and populations and outcomes that do not directly generalise to the population of interest. In addition, it was challenging to integrate data across diverse disability insurance and health care systems.

Consequently, there is no one intervention that we have found that can be recommended as effective for the four main outcomes suggested by the stakeholders (prevention and management of work disability/sickness absence, work functioning and recurrences of work disability/sickness absence).

The results from our review are consistent with those of one recently published Cochrane review that evaluated the effects of interventions aimed at reducing sickness absence/work disability in depressed workers [35]. They concluded that there was no evidence of an effect of medication alone, enhanced primary care, psychological interventions or combinations on sickness absence of depressed workers. Other recently published systematic 
reviews were not focused on depression [36, 37], or did not focus on working populations $[38,39]$. Others focused on clinical (e.g., improvement in depression) or process of care outcomes (e.g., medication adherence), rather than work-related outcomes of more direct relevance to workplaces [40, 41]. Examples of such outcomes have been previously described using a classification framework informed by stakeholders of Ontario's health and safety system (Table 1) and may be informative for future research in this area. There are narrative reviews [42, 43] concluding that cognitive-behavioural therapy and interpersonal therapy reduce work disability and are costeffective.

It is interesting to note that the majority of the included studies were not "workplace-based" or "work-directed" in terms of the setting or approach. Most studies concerned clinical interventions focused on the individual worker, often within the (collaborative or enhanced) health care setting. These clinical interventions might be implemented or facilitated by the employer to manage depression in the workplace-depending on the health care and jurisdictional context. However, along with the worker-focused intervention approaches which might be feasible and need further evaluation, particular challenges and barriers in the implementation of interventions to manage depression in the workplace have to be addressed. For example, in their recent report on best practices for return-to-work/stayat-work interventions for workers with mental health conditions, Pomaki et al. [36] conclude among others that more research is needed to better understand stigma and discrimination, to increase supervisor and co-worker awareness and support, and to focus on work and the workplace. Future studies might consider to combine organizationallevel interventions with work(er-)-focused interventions.

It is not yet known the optimal timing of the intervention in the course of a depressive episode, and the duration of the intervention's effect. It is unknown whether the positive results reported in some studies generalise to different compensation and health care systems. The review clearly showed the challenges in the definition and interpretation of work-related outcomes (such as sickness absence or work disability) across studies from different jurisdictions. Interventions and programs aiming at these work-related outcomes are shaped by the health care and jurisdictional context, and may not be directly relevant to other jurisdictions.

\section{Strengths and Limitations of the Review}

Our review was conducted by an international and multidisciplinary team, who received input and feedback from a Canadian stakeholder group. Stakeholder involvement was essential in shaping the research question, suggesting terms for the literature search, prioritising outcome measures, and interpreting the key findings.

Even though we used a comprehensive search with broad inclusion criteria, it is possible some relevant studies were still missed. We used a validated method to judge the risk of bias of the included studies, but the judgments are in most cases subjective. Our choice to do a qualitative synthesis instead of a meta-analysis pooling was directed by the type of data, but it could have been argued that our choice was not the most appropriate.

Given the prevalence of depression in the workplace and the costs associated with work disability and productivity loss at work, even a small effect size with economic benefits may be regarded as relevant to employers and employees. Although ten of the 12 included studies used a randomised controlled design, there were many features of study design, study performance or analyses that jeopardised validity. For instance, due to the inherent nature of these interventions, all included studies lacked the ability to appropriately blind intervention providers and participants to the intervention, introducing the risk of performance and measurement biases. Several studies featured inadequate descriptions of participation and adherence to the proposed interventions, potential differences between participants and non-participants, potential differences between remaining participants and those lost to follow-up, or the methods used to randomly allocate individuals. Contamination was also a problem in several studies, while some studies did not account for baseline differences between groups in the analysis.

\section{Implications}

Future studies should reduce the risk of bias by focusing on randomised trials, blinding, and to adhere to the CONSORT standards for description and reporting [44]. Blinding participants to the intervention received is challenging, but cluster randomisation may facilitate this. Future studies should also describe the baseline working status (working or on disability/sick leave) and attempt to report the result for each distinct baseline working status in order to more specifically address whether an intervention is effective to prevent work disability/sickness absence or to manage work disability/sickness absence. There is also a need for valid and reliable outcome measures, and a consensus on what should be measured when approaching productivity or loss of productivity at work.

The problem of depression in the workplace is complex, with consequences to the worker and their families, coworkers, supervisors and employers, disability insurers, and government. No single intervention approach was shown to be effective to manage workers with depression, but the current review provides some direction for future 
research in terms of types of feasible interventions, study design, and framework for outcome measures.

Acknowledgments Nancy Carnide is supported by a Canadian Institutes of Health Research Vanier Canada Graduate Scholarship. Kimberley Cullen is supported by a National Sciences and Engineering Research Council of Canada Graduate Scholarship. The team is grateful to Quenby Mahood and Joanna Liu for their assistance with literature searches and article retrieval. We would also like to thank all of the stakeholders who participated in our two meetings.

Conflict of interests All authors have completed the Unified Competing Interest form at www.icmje.org/coi_disclosure.pdf (available on request from the corresponding author) and declare: no financial relationships with any organisations that might have an interest in the submitted work in the previous 3 years; no other relationships or activities that could appear to have influenced the submitted work.

Funding This review was funded by the Canadian Institutes of Health Research, Evidence on Tap-Expedited Knowledge Synthesis-Competition 200911ETP.

Open Access This article is distributed under the terms of the Creative Commons Attribution Noncommercial License which permits any noncommercial use, distribution, and reproduction in any medium, provided the original author(s) and source are credited.

\section{References}

1. Hirschfeld RM, Montgomery SA, Keller MB, Kasper S, Schatzberg AF, Moller HJ, et al. Social functioning in depression: a review. J Clin Psychiatry. 2000;61(4):268-75.

2. Stephens T, Joubert N. The economic burden of mental health problems in Canada. Chronic Dis Can. 2001;22(1):18-23.

3. Murray CJ, Lopez AD. Alternative projections of mortality and disability by cause 1990-2020: global burden of disease study. Lancet. 1997;349(9064):1498-504.

4. Stewart WF, Ricci JA, Chee E, Hahn SR, Morganstein D. Cost of lost productive work time among US workers with depression. JAMA. 2003;289(23):3135-44.

5. Adler DA, McLaughlin TJ, Rogers WH, Chang H, Lapitsky L, Lerner D. Job performance deficits due to depression. Am J Psychiatry. 2006;163(9):1569-76.

6. Wang PS, Beck AL, Berglund P, McKenas DK, Pronk NP, Simon GE, et al. Effects of major depression on moment-in-time work performance. Am J Psychiatry. 2004;161(10):1885-91.

7. Kessler RC, Barber C, Birnbaum HG, Frank RG, Greenberg PE, Rose RM, et al. Depression in the workplace: effects on shortterm disability. Health Aff (Millwood). 1999;18(5):163-71.

8. Lerner D, Adler DA, Chang H, Lapitsky L, Hood MY, Perissinotto $\mathrm{C}$, et al. Unemployment, job retention, and productivity loss among employees with depression. Psychiatry Serv. 2004;55(12):1371-8.

9. Greenberg PE, Stiglin LE, Finkelstein SN, Berndt ER. The economic burden of depression in 1990. J Clin Psychiatry. 1993;54(11):405-18.

10. Kessler RC, Akiskal HS, Ames M, Birnbaum H, Greenberg P, Hirschfeld RM, et al. Prevalence and effects of mood disorders on work performance in a nationally representative sample of U.S. workers. Am J Psychiatry. 2006;163(9):1561-8.
11. Sanderson K, Tilse E, Nicholson J, Oldenburg B, Graves N. Which presenteeism measures are more sensitive to depression and anxiety? J Affect Disord. 2007;101(1-3):65-74.

12. Burton WN, Pransky G, Conti DJ, Chen CY, Edington DW. The association of medical conditions and presenteeism. J Occup Environ Med. 2004;46(6 Suppl):S38-45.

13. Lerner D, Henke RM. What does research tell us about depression, job performance, and work productivity? J Occup Environ Med. 2008;50(4):401-10.

14. Goetzel RZ, Ozminkowski RJ, Sederer LI, Mark TL. The business case for quality mental health services: why employers should care about the mental health and well-being of their employees. J Occup Environ Med. 2002;44(4):320-30.

15. Higgins JPT, Green S (eds) [Internet]. Cochrane handbook for systematic reviews of interventions version 5.1.0 [updated March 2011]. 2011 [cited 2011 Jan 5]; Available from: URL: http://www.cochrane-handbook.org/.

16. Evidence Partners Incorporated [Internet]. DistillerSR. (Webbased systematic review software). 2010; Available from: URL: http://systematic-review.net/.

17. Brewer S, Van Eerd D, Amick BC III, Irvin E, Daum KM, Gerr F, et al. Workplace interventions to prevent musculoskeletal and visual symptoms and disorders among computer users: a systematic review. J Occup Rehabil. 2006;16(3):325-58.

18. Van Eerd D, Brewer S, Amick BC III, Irvin E, Daum K, Gerr F. Workplace interventions to prevent musculoskeletal and visual symptoms and disorders among computer users: a systematic review. Toronto: Institute for Work \& Health; 2006.

19. Guyatt GH, Oxman AD, Schunemann HJ, Tugwell P, Knottnerus A. GRADE guidelines: a new series of articles in the Journal of Clinical Epidemiology. $\mathrm{J}$ Clin Epidemiol. 2010;64(4):380-2.

20. Blonk RWB, Brenninkmeijer V, Lagerveld SE, Houtman ILD. Treatment of work- related psychological complaints: a randomized field experiment among self-employed. Work and Stress. 2006;20:129-44.

21. Rebergen DS, Bruinvels DJ, Bezemer PD, van der Beek AJ, van Mechelen W. Guideline-based care of common mental disorders by occupational physicians (CO-OP study): a randomized controlled trial. J Occup Environ Med. 2009;51(3):305-12.

22. Rebergen DS, Bruinvels DJ, van Tulder MW, van der Beek AJ, van Mechelen W. Cost-effectiveness of guideline-based care for workers with mental health problems. J Occup Environ Med. 2009;51(3):313-22.

23. Schene AH, Koeter MWJ, Kikkert MJ, Swinkels JA, McCrone P. Adjuvant occupational therapy for work-related major depression works: randomized trial including economic evaluation. Psychol Med J Res Psychiatry Allied Sci. 2007;37(3):351-62.

24. van der Feltz-Cornelis CM, Hoedeman R, de Jong FJ, Meeuwissen JAC, Drewes HW, van der Laan NC. Faster return to work after psychiatric consultation for sicklisted employees with common mental disorders compared to care as usual. A randomized clinical trial. Neuropsychiatry Dis Treat. 2010;6: 375-85.

25. Lo Sasso AT, Rost K, Beck A. Modeling the impact of enhanced depression treatment on workplace functioning and costs: a costbenefit approach. Med Care. 2006;44(4):352-8.

26. Rost K, Smith JL, Dickinson M. The effect of improving primary care depression management on employee absenteeism and productivity. A randomized trial. Med Care. 2004;42(12):1202-10.

27. Schoenbaum M, Unutzer J, Sherbourne C, Duan N, Rubenstein LV, Miranda J, et al. Cost-effectiveness of practice-initiated quality improvement for depression: results of a randomized controlled trial. JAMA. 2001;286(11):1325-30.

28. Smith JL, Rost KM, Nutting PA, Libby AM, Elliott CE, Pyne JM. Impact of primary care depression intervention on employment 
and workplace conflict outcomes: is value added? J Ment Health Policy Econ. 2002;5(1):43-9.

29. Wang PS, Simon GE, Avorn J, Azocar F, Ludman EJ, McCulloch $\mathrm{J}$, et al. Telephone screening, outreach, and care management for depressed workers and impact on clinical and work productivity outcomes: a randomized controlled trial. JAMA. 2007;298(12): 1401-11.

30. Dewa CS, Hoch JS, Carmen G, Guscott R, Anderson C. Cost, effectiveness, and cost-effectiveness of a collaborative mental health care program for people receiving short-term disability benefits for psychiatric disorders. Can J Psychiatry. 2009;54(6): 379-88.

31. Knekt P, Lindfors O, Laaksonen MA, Raitasalo R, Haaramo P, Jarvikoski A, et al. Effectiveness of short-term and long-term psychotherapy on work ability and functional capacity-a randomized clinical trial on depressive and anxiety disorders. J Affect Disord. 2008;107(1-3):95-106.

32. Knekt $\mathrm{P}$, Lindfors $\mathrm{O}$, Harkanen $\mathrm{T}$, Valikoski M, Virtala E, Laaksonen MA, et al. Randomized trial on the effectiveness of long-and short-term psychodynamic psychotherapy and solutionfocused therapy on psychiatric symptoms during a 3-year followup. Psychol Med. 2008;38(5):689-703.

33. Krogh J, Saltin B, Gluud C, Nordentoft M. The DEMO trial: a randomized, parallel-group, observer-blinded clinical trial of strength versus aerobic versus relaxation training for patients with mild to moderate depression. J Clin Psychiatry. 2009;70(6): 790-800.

34. Kawakami N, Araki S, Kawashima M, Masumoto T, Hayashi T. Effects of work-related stress reduction on depressive symptoms among Japanese blue-collar workers. Scand J Work Environ Health. 1997;23(1):54-9.

35. Nieuwenhuijsen K, de Boer AG, Verbeek JH, Blonk RW, van Dijk FJ. The Depression Anxiety Stress Scales (DASS): detecting anxiety disorder and depression in employees absent from work because of mental health problems. Occup Environ Med. 2003;60(Suppl 1):i77-82.

36. Pomaki G, Franche RL, Khushrushahi N, Murray E, Lampinen T, Mah P. Best practices for return-to-work/stay-at-work interventions for workers with mental health conditions. Final report. Vancouver, BC: Occupational Health and Safety Agency for Healthcare in BC (OHSAH); 2010.

37. Corbière M, Shen J, Rouleau M, Dewa CS. A systematic review of preventive interventions regarding mental health issues in organizations. Work. 2009;33(1):81-116.

38. Williams JW Jr, Gerrity M, Holsinger T, Dobscha S, Gaynes B, Dietrich A. Systematic review of multifaceted interventions to improve depression care. Gen Hosp Psychiatry. 2007;29(2): 91-116.

39. Lawlor DA, Hopker SW. The effectiveness of exercise as an intervention in the management of depression: systematic review and meta-regression analysis of randomised controlled trials. BMJ. 2001;322(7289):763-7.

40. Badamgarav E, Weingarten SR, Henning JM, Knight K, Hasselblad V, Gano A Jr, et al. Effectiveness of disease management programs in depression: a systematic review. Am J Psychiatry. 2003;160(12):2080-90.

41. Gilbody S, Bower P, Fletcher J, Richards D, Sutton AJ. Collaborative care for depression: a cumulative meta-analysis and review of longer-term outcomes. Arch Intern Med. 2006;166(21):2314-21.

42. Markowitz JC. Evidence-based psychotherapies for depression. J Occup Environ Med. 2008;50(4):437-40.

43. Myhr G, Payne K. Cost-effectiveness of cognitive-behavioural therapy for mental disorders: implications for public health care funding policy in Canada. Can J Psychiatry. 2006;51(10):662-70.

44. Moher D, Hopewell S, Schulz KF, Montori V, Gotzsche PC, Devereaux PJ, et al. CONSORT 2010 explanation and elaboration: updated guidelines for reporting parallel group randomised trials. BMJ. 2010;340:c869. 